\title{
Analisis Bandgap Karbon Nanodots (C-Dots) Kulit Bawang Merah Menggunakan Teknik Microwave
}

\author{
Diana Triwardiati*, Imas Ratna Ermawati \\ Fakultas Keguruan dan Ilmu Pendidikan \\ Universitas Muhammadiyah Prof. DR. HAMKA Jakarta \\ dianatriwardiati@gmail.com* \\ imas_re@uhamka.ac.id
}

\begin{abstract}
Abstrak - Penelitian ini bertujuan untuk mengetahui sifat fisis dan bandgap dari hasil sintesis karbon nanodots (c-dots) kulit bawang merah menggunakan teknik microwave yang kemudian diuji menggunakan alat spektrometer uv-vis. Penelitian ini dilakukan di Laboratorium Fisika-IPB Babakan Dramaga, Bogor, Jawa Barat. Sintesis c-dots dilakukan dengan mengekstrasi kulit bawang merah dan aquades dengan blender, kemudian dimasukan dalam microwave dengan variasi waktu pemanasan selama 5 menit, 10 menit, 15 menit, dan 20 menit. Setelah itu, dilakukan penyaringan agar mendapatkan c-dots yang homogen. Selanjutnya pengujian bandgap dilakukan dengan alat spektrometer uv-vis dengan rentang panjang gelombang 190-800 nm. Hasil yang diperoleh dari alat spektrometer uv-vis berupa grafik yang menggambarkan hubungan antara nilai absorbansi dan panjang gelombang. Dari percobaan yang telah dilakukan selama 5 kali pengulangan dan perhitungan yang telah dilakukan diperoleh nilai rata-rata bandgap secara berturut-turut sebesar 3,5826 eV, 2,6888 eV, 2,4222 eV, dan 1,11378 eV. Lamanya waktu pemanasan dalam microwave berpengaruh terhadap nilai absorbansi. Dimana nilai absorbansi rata-ratanya adalah 0,76806, 1,21406, 1,3186, 1,74068. Hal Ini menunjukan bahwa semakin besar nilai absorbansi, maka bandgap yang dihasilkannya semakin kecil. Rendahnya bandgap karena energi yang diperlukan untuk eksitasi elektron dari pita valensi ke pita konduksi semakin rendah pula.
\end{abstract}

Kata Kunci : c-dots, kulit bawang merah, microwave, bandgap

\section{Pendahuluan}

Indonesia merupakan negara tropis yang banyak ditumbuhi tanaman. Tanaman ini banyak sekali yang bisa dimanfaatkan oleh masyarakat, baik sebagai bahan pangan maupun sebagai bahan obat-obatan. Namun, untuk limbah tanaman masih jarang dimanfaatkan oleh masyarakat. Salah satu contoh limbah tanaman tersebut yaitu kulit bawang merah. Kulit bawang merah berasal dari tumbuhan bawang merah yang memiliki nama latin Aliium cepta $L$. Kandungan senyawa aktif kulit bawang merah yaitu flavonoid, antioksidan, allisin, pektin, dan fitosterol.[1] Informasi mengenai kulit bawang merah ini masih terbatas dan pemanfaatnya masih kurang dilakukan oleh masyarakan, karena itu kulit bawang merah ini akan dimanfaatkan dalam proses sintesis nanomaterial yang hasilnya dapat diaplikasikan dalam bidang nanoteknologi. Salah satu nanomaterial yang sedang dan terus dikembangkan adalah karbon nanodots (c-dots).

Karbon nanodots (c-dots) merupakan salah satu nanomaterial karbon yang berukuran 2-10 nm, berstruktur amorf, dan berbentuk bola. Karbon nanodots(c-dots) mempunyai kelarutan yang tinggi jika direaksikan dengan air, dan tidak beracun. Aplikasi karbon nanodots (c-dots) ini dapat dibagi menjadi dua, yaitu aplikasi dalam ilmu bahan (material science) dan aplikasi berorientasi biologis. Dalam ilmu bahan, karbon nanodots (c-dots) ini berguna sebagai sensor kimiawi, sel surya, dan berbagai aplikasi lainnya dalam bidang optoelektronika dan fotonika. Sedangkan, aplikasi biologis karbon nanodots berguna dalam hal bioimaging dan biosensor, serta berpotensi sebagai agen terapeutik untuk beberapa penyakit. Aplikasi yang lebih menonjol untuk karbon dot adalah aplikasi berorientasi biologis.[2] Karena dapat dibuat dari bahan organik yang mudah untuk ditemukan.

Secara umum dalam membuat karbon nanodots (cdots) terdapat dua cara, yaitu metode sintesis bottom-up dan top-down. Metode sintesis bottom-up yaitu memecah karbon dot dari molekul mentah (raw materials). Metode sintesis bottom-up diantaranya adalah pembakaran, microwave, hidotermal, ultrasonik, supported synthetic, dan oksidasi asam. Sedangkan metode sintesis top-down yaitu cara memecah partikel berukuran besar menjadi partikel berukuran nanometer. Metode sintesis top-down diantaranya adalah ablasi laser, sintesis elektronikimia, plasma treatment, dan arc discharge. 
Bebagai macam penelitian mengenai sintesis karbon nanodots (c-dots) telah banyak dilakukan dengan metode yang berbeda-beda untuk mengetahui sifat optik. Karena dari sifat optik ini dapat diketahui pendaran dari sampel dan apakah sampel yang dipakai dapat terbentuk karbon nanodots (c-dots). Karbon nanodots (c-dots) yang akan dibuat ini berasal dari bahan organik yaitu kulit bawang merah merupakan limbah dapur yang mudah ditemukan. Pembuatan karbon nanodots (c-dots) ini menggunakan teknik microwave yang dilakukan dengan proses pemanasan menggunakan gelombang mikro. Prinsip dari metode microwave adalah menggetarkan molekul, sehingga menyebabkan rantai-rantai karbon mengalami penyusunan ulang sehingga hasilnya tidak banyak mengurangi kadar air dalam larutan dan tidak akan dihasilkan karbon nanodots (c-dots) berupa gel. Oleh karena itu, tujuan dari penelitian ini adalah untuk membuat karbon nanodots (c-dots) dari kulit bawang merah serta mengetahui bandgap dari nilai spektrum absorbansi yang dapat diukur menggunakan alat spektrometer uv-vis.

\section{Dasar Teori}

\section{Bandgap}

Energi band gap adalah energi minimum yang dibutuhkan untuk mengeksitasi elektron dari pita valensi ke pita konduksi.[3] Berdasarkan pengisian elektron, pita energi dapat dibedakan menjadi 2 jenis, yaitu pita valensi dan pita konduksi. Pita valensi adalah pita energi teratas yang terisi penuh oleh elektron, dan pita konduksi adalah pita energi yang berada di atas pita valensi yang terisi oleh sebagian atau tidak terisi sama sekali oleh elektron.

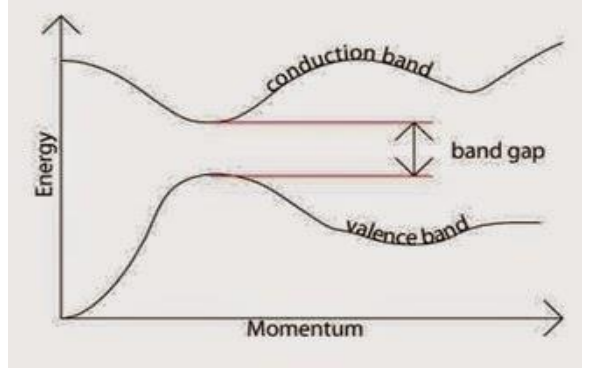

Gambar 2.1. Bandgap Pada Semikonduktor

Pada umumnya, diantara pita valensi dan pita konduksi terdapat suatu celah yang disebut dengan celah energi. Lebar celah diantara pita energi yang disebut sebagai daerah larangan (forbidden region). Di kawasan ini tidak boleh ada elektron, dan fungsi gelombang elektron pun tak diperkenankan dikawasan ini, sebab menurut larangan Pauli bahwa disetiap subkulit hanya boleh memiliki sejumlah elektron tertentu.

Lebar dari pita energi bergantung pada jenis bahan, fungsi gelombang atom, serta struktur dari suatu zat bersifat konduktor, isolator, atau semi konduktor. Bahan konduktor memiliki celah daerah terlarang yang sempit, sehingga elektron di pita tertentu mudah berpindah ke pita yang lain oleh medan listrik yang kecil.[4] Hal ini disebabkan karena elektron pada pada pita valensi mengalami kekosongan dibandingkan dengan pita konduksi yang penuh terisi elektron. Sedangkan bahan isolator memiliki celah daerah larangan yang besar, karena elektron akan mengalami kesulitan untuk loncat dari pita konduksi ke pita valensi.

Ketika suatu semikonduktor dikenai energi yang sesuai dengan energi celah pita, maka elektron akan tereksitasi ke pita konduksi sehingga meninggalkan muatan positif yang disebut hole. Sebagian besar dari pasangan elektron-hole tersebut akan bertahan di permukaan semikonduktor, sehingga hole dapat bekerja dengan menginisiasi reaksi oksidasi dan elektron menginisiasi reaksi reduksi senyawa kimia yang ada disekitarnya. Perbedaan bandgap atau disebut juga dengan energi gap (Eg) ini dipengaruhi oleh lingkungan kristal masingmasing atom penyusun kristalnya.

Persamaan untuk menentukan energi gapnya yaitu:

$$
\alpha^{2}=\frac{h c}{\lambda}-E_{g}
$$

\section{Karbon Nanodots (C-Dots)}

Karbon nanodots (c-dots) didefinisikan sebagai material karbon berukuran nanopartikel yang berdimeni nol dengan ukuran 2-10 $\mathrm{nm}$ serta memiliki karakteristik menyerupai logam berat berbasis quantum dots.[5] Karbon nanodots memiliki keunikan sifat yaitu materialnya dapat memancarkan (mengemisikan) cahaya ketika disinari sinar UV, dengan panjang gelombang emisi atau warna pendaran cahaya akan bergantung pada lebar celah pita karbon nanodots.[6] Selain itu sifat keunggulan lain dari carbon nanodots diantaranya bersifat inert, mudah terlarut dalam air, tidak beracun, serta tidak mudah fotobleaching.[7]

Karbon nanodots mampu mengemisikan cahaya karena adanya proses pengurungan kuantum, efek pengurungan kuantum ini membuat adanya pelebaran pita karena bandgapnya lebih besar maka energi eksitasinya akan lebih besar, energi eksitasi membesar maka energi deeksitasinyapun akan besar sehingga emisinya akan besar juga. Proses eksitasi tersebut sangat

erat hubungannya dengan ukuran partikel dari nanodots. Ketika ukuran karbon mengecil sampai ukuran karbon nanodots, lebar celah pita (bandgap) yang dimiliki menjadi lebih besar dibanding saat bulknya. Hal ini mengakibatkan adanya pergeseran warna biru pada spektrum cahaya eksitasi dan emisi. Selain itu, pitaenergi tersebut akan menjadi diskrit.

Sintesis nanopartikel dengan cara memecah partikel berukuran besar menjadi partikel berukuran nanometer disebut metode top-down. Metode dengan memulai dari atom-atom atau molekul-molekul yang membentuk partikel berukuran nanometer yang dikehendaki disebut metode bottom-up. Metode sintesis yang termasuk ke dalam kategori top-down di antaranya ablasi laser, sintesis elektrokimia, plasma treatment, dan arc discharge. Sedangkan, metode sintesis yang termasuk ke dalam kategori bottom-up adalah pembakaran, microwave, hidrotermal, ultrasonik, supported synthetic, dan oksidasi asam. 

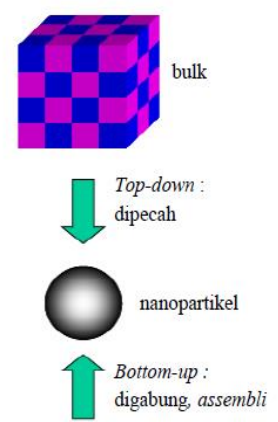

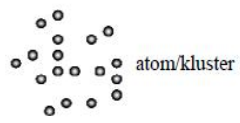

Gambar 2.2. Metode Sintesis Top-Down dan Battom-Up

\section{Bawang Merah}

Bawang merah merupakan tumbuhan semusim yang memiliki umbi berlapis. Dimana umbi lapis terdiri dari daun-daun yang telah menjadi tebal, lunak, dan berdaging.[8] Tanaman bawang merah memiliki kuncup samping (gemma lateralis) yang merupakan calon tunastunas daun. Kuncup samping bawang merah tumbuh berupa umbi lapis kecil-kecil, berkelompok disekitar umbi induknya.

Tumbuhan bawang merah memiliki akar serabut yang merupakan akar sejati. Akar serabut ini tumbuh langsung dari akar yang tumbuh sama fungsi dan strukturnya dengan akar serabut pada tumbuhan lainnya.[9] Tumbuhan bawang merah berdasarkan sifat dan bentuk sisiknya memiliki sisik yang berlapis (bulbus). Bulbus yang lebar dan yang bagian luar menyelubungi bagian dalam, sehingga jika tanaman bawang merah diiris membujur akan nampak dengan jelas susunan yang berlapis-lapisnya.

Tumbuhan bawang merah memiliki nama latin Aliium cepta L. Tanaman bawang merah berasal dari daerah Asia Tengah yakni sekitar Banglades, India, dan Pakistan. Tanaman Bawang merah di Indonesia banyak ditanam di daerah Brebes. Tanaman bawang merah tumbuh di daerah sekitar 560 - $1000 \mathrm{~m}$ diatas permukaan laut dan banyak ditanam didaerah dataran rendah.

Tanaman bawang merah memiliki kandungan vitamin C, kalium, serat, dan asam folat. Selain itu, bawang merah mengandung kalsium dan zat besi..bawang merah juga mengandung zat pengatur tumbuh alami berupa hormon auksin dan giberelin.

Masyarakat biasanya hanya memanfaatkan bawang merahnya saja sebagai bahan pangan, sedangkan kulit bawang merah dibuang begitu saja. Padahal kulit bawang merah mempunyai kandungan yang tidak banyak orang yang tahu. Kandungan senyawa aktif kulit bawang merah yaitu flavonoid, antioksidan, allisin, pektin, dan fitosterol.[10] Kulit bawang merah ini bisa manfaatkan sebagai obat yaitu sebagai antiflemasi[11] dan antioksidan.[12]

\section{Microwave}

Microwave merupakan salah satu peralatan dapur yang memanfaatkan energi gelombang mikro untuk mengolah bahan makanan. Gelombang ini merupakan gelombang radio yang memiliki berfrekuensi sebesar $2,5 \mathrm{GHz}$, dan memiliki panjang gelombang antara $1 \mathrm{~mm}$ sampai $1 \mathrm{~m}$. Panjang gelombang pada microwave lebih pendek daripada panjang gelombang biasanya.

Metode microwave menyediakan energi yang intensif, homogen, serta dapat mencapai suhu tinggi dan memulai reaksi dalam waktu yang sangat singkat.[13] Perpindahan energi dari gelombang mikro pada material dikarenakan oleh mekanisme dipolar polarization, ionicconduction, dan inuterfacial polarization yang menyebabkan superheating secara cepat pada material. Jika sebuah molekul terkena radiasi gelombang mikro maka dipole mencoba mensejajarkan dengan bentuk gelombang mikro. Jika gelombang mikro terus dipancarkan secara cepat (oscillating), dipole akan secara terus menerus mengikuti gerak gelombang tersebut. Pergantian orientasi dari molekul tersebut akan menyebabkan gesekan dan akan menimbulkan panas.[14]

Prinsip dari metode microwave adalah menggetarkan molekul sehingga c-dotsdari metode microwave lebih unggul karena prosesnya penggetaran (vibrasi) yang menyebabkan rantai-rantai karbon mengalami penyusunan ulang sehingga hasilnya tidak banyak mengurangi kadar air dalam larutan dan tidak akan dihasilkan c-dots berupa gel.

Sintesis pembuatan karbon nanodots (c-dots) menggunakan teknik microwave memiliki tahapan sebagai berikut:

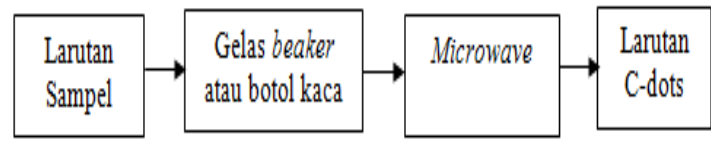

Gambar 2.3. Proses Sintesis Menggunakan Teknik Microwave

\section{Spektrometer Uv-vis}

Menurut Giancoli, spektrometer adalah alat untuk mengukur panjang gelombang akurat dengan menggunakan kisi difraksi atau prisma, untuk memisahkan panjang gelombang yang berbeda.[15] Kegunaan dari spektromer yaitu untuk mengidentifikasi atom atau molekul. Ketika gas dipanaskan atau arus listrik yang besar melewatinya, gas tersebut memancarkan spektrum garis karakteristik.

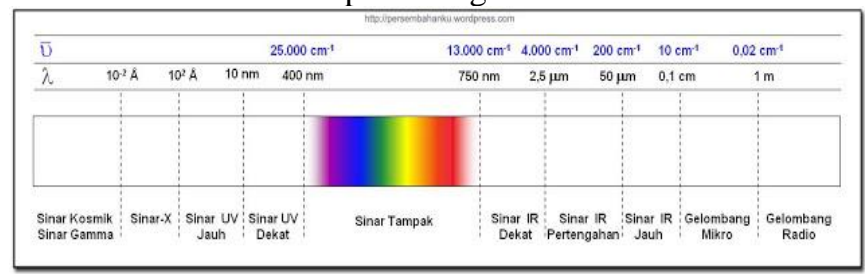

Gambar 2.4. Spektrum Garis Karakteristik

Sedangkan spektrometer uv-vis adalah anggota teknis analisis spektroskopi memakai sumber radiasi elektromagnetik ultraviolet dekat $(190-380 \mathrm{~nm})$ dan sinar tampak $(380$ - $780 \mathrm{~nm})$ dengan memakai instrumen spektrofotometer.[16] Spektrofotometer adalah metode pengukuran kuantitatif yang didasarkan pada pengukuran absorbansi (penyerapan) radiasi gelombang 
elektromagnetik. Spektrofotometri ini dapat melakukan pengukuran konsentrasi larutan dengan menggunakan instrumen yang digunakan untuk mengukur jumlah cahaya yang diserap atau intensitas warna yang sesuai dengan panjang gelombang.

Bagian utama dari spektrofotometer adalah sumber radiasi elektromagnet, monoktromator, sel, detektor fotolistrik dan perlalatan penunjuk output dari detek (elektrikmeter, potensiometer, atau potensiometer pencatat). Bagian sel mengandung sel serapan optik berisi larutan yang dipelajari dan sel serapan lain yang berisi larutan pembanding; umumnya dipakai pelarut murni. Perbandingan intensitas I dari sinar yang diteruskan oleh larutan terhadap intensitas I untuk pelarut disebut transmitans.[17]

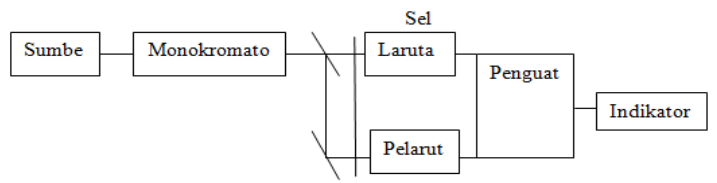

Gambar 2.5.Spektrofotometer. Sumber dan Monokromator Dapat Diganti dengan Laser yang Dapat Di “tune”.

Hasil dari penggunaan spektrometer uv-vis berupa grafik hubungan antara panjang gelombang dengan absorbansinya, grafik ini sudah tercatat secara otomatis. Radiasi spektrometer uv-vis yang memiliki frekuensi yang sama dengan sampelnya akan beresonansi yang mengakibatkan radiasinya diserap oleh sampel. Absorbansi ini mengakibatkan terjadinya transisi elektron, yaitu elektron-elektron dari orbital dasar tereksitasi ke orbital yang lebih tinggi. Ketika elektron kembali ke orbital asal, elektron tersebut memancarkan energi dan energi itulah yang terdeteksi sebagai puncak-puncak absorbansi.

Kebolehjadian terserapnya foton umumnya berbanding langsung dengan konsentrasi molekul penyerap dan tebal contoh yang sangat tipis. Secara matematik kebolehjadian ini dinyatakan sebagai hukum Lamber-Beer.

$$
\begin{gathered}
\log \frac{I_{0}}{I}=A=\in c l \\
\text { Dengan } \in=\frac{k}{2,303} \text { sebagai koefisien sarapan molar }
\end{gathered}
$$
dan c sebagai konsentrasi zat. Besaran $\log \mathrm{I}_{0} / \mathrm{I}$ dinyatakan sebagai serapan (absorbansi). Tetapan serapan semu dari zat yang terasosiasi atau terdisosiasi akan berubah dengan konsentrasi karena perbandingan konsentrasi spasi penyerap berubah.

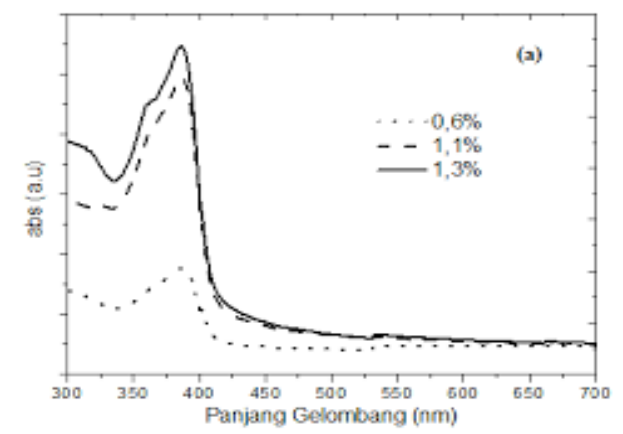

Gambar 2.6.Grafik Hubungan Panjang Gelombang dengan Absorbansi Suatu Zat yang Dikeluarkan Spektrometer Uv-vis.

\section{Metodologi Penelitian}

Penelitian ini bertujuan untuk melakukan sintesis karbon nanodots (c-dots) kulit bawang merah, mengetahui sifat fisis, serta menganalisis bandgap yang dihasilkan dari karbon nanodots (c-dots) kulit bawang merah dengan menggunakan teknik microwave.

Penelitian ini dilaksanakan di Laboratorium Fisika - IPB Babakan Dramaga, Bogor, Jawa Barat.

Pengambilan data dilakukan dengan pemaparan radiasi microwave untuk 4 botol sampel dengan waktu yang berbeda setiap sampelnya yaitu 5 menit, 10 menit, 15 menit, dan 20 menit. Pemaparan radiasi menggunakan microwave untuk membuat karbon nanodots (c-dots), setelah itu dilakukan pengujian menggunakan spektrometer Uv-vis pada setiap sampel karbon nanodots (c-dots) kulit bawang merah untuk mengetahui bandgap dari masingmasing sampel.

\section{Temuan dan Pembahasan}

Dari penelitian yang telah dilakukan diperoleh hasil ekstrasi kulit bawang merah sebanyak 10 gram dengan aquades sebanyak $300 \mathrm{ml}$ berupa larutan yang berwarna kecoklatan. Sampel karbon nanodots (c-dots) kulit bawang merah menggunakan teknik microwave pada suhu $150^{\circ} \mathrm{C}$ menghasilkan sifat fisis pada waktu pemanasan selama 5 menit, 10 menit, 15 menit, dan 20 menit menunjukan warna pada larutannya dari kuning kecoklatan menjadi kecoklatan dan hasil larutan tidak menjadi gel.

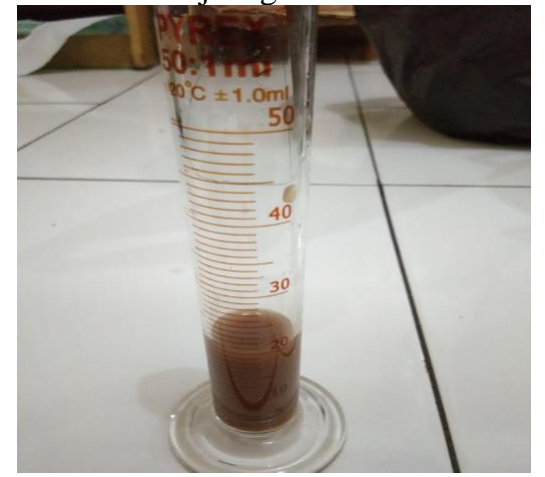

Gambar 4.1. Larutan Hasil Perlakuan Sebelum Pemanasan dalam Microwave

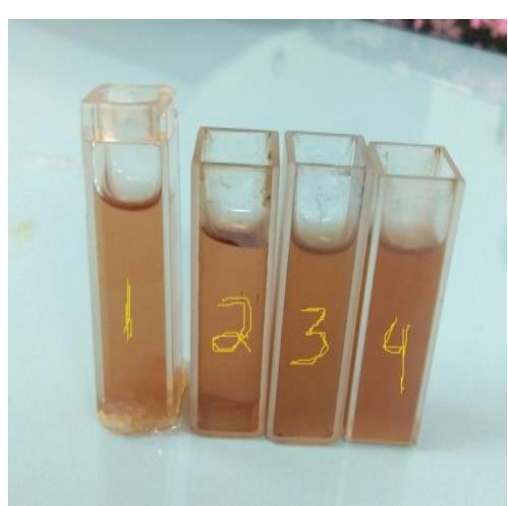

Gambar 4.2.Larutan Hasil Perlakuan Sesudah Pemanasan dalam Microwave 
Karbon nanodots (c-dots) kulit bawang merah diuji menggunakan alat spektrometer uv-vis. Data yang diperoleh dari uji Uv-vis dengan rentang panjang gelombang 190-800 $\mathrm{nm}$ berupa nilai absorbansi. Data hasil percobaan yang telah dilakukan pada waktu pemanasan dalam microwave selama 5 menit, 10 menit, 15 menit, dan 20 menit disajikan dalam bentuk tabel dibawah.

Tabel 4.1. Data Hasil Percobaaan

\begin{tabular}{|c|c|c|c|c|c|c|}
\hline $\begin{array}{c}\text { Waktu } \\
\text { Pemanasan }\end{array}$ & $\lambda(\mathrm{nm})$ & $\bar{\lambda}(\mathrm{nm})$ & $\alpha$ & $\bar{\alpha}$ & $E_{g}(\mathrm{eV})$ & $\bar{E}_{g}(\mathrm{eV})$ \\
\hline \multirow{5}{*}{5 menit } & 300 & \multirow{5}{*}{296,6} & 0,7765 & \multirow{5}{*}{0,76806} & 3,536 & \multirow{5}{*}{3,5826} \\
\hline & 296 & & 0,7596 & & 3,618 & \\
\hline & 300 & & 0,7718 & & 3,543 & \\
\hline & 296 & & 0,7655 & & 3,609 & \\
\hline & 296 & & 0,7669 & & 3,607 & \\
\hline \multirow{5}{*}{10 menit } & 298 & \multirow{5}{*}{298,2} & 1,2127 & \multirow{5}{*}{1,21406} & 2,695 & \multirow{5}{*}{2,6888} \\
\hline & 298 & & 1,2176 & & 2,683 & \\
\hline & 299 & & 1,2459 & & 2,600 & \\
\hline & 297 & & 1,1906 & & 2,762 & \\
\hline & 299 & & 1,2035 & & 2,704 & \\
\hline \multirow{5}{*}{15 menit } & 295 & \multirow{5}{*}{298,4} & 1,3333 & \multirow{5}{*}{1,3186} & 2,432 & \multirow{5}{*}{2,4222} \\
\hline & 299 & & 1,3244 & & 2,398 & \\
\hline & 300 & & 1,3153 & & 2,409 & \\
\hline & 299 & & 1,3191 & & 2,412 & \\
\hline & 299 & & 1,3009 & & 2,46 & \\
\hline \multirow{5}{*}{20 menit } & 300 & \multirow{5}{*}{299,5} & 1,7791 & \multirow{5}{*}{1,74068} & 0,974 & \multirow{5}{*}{1,11378} \\
\hline & 299 & & 1,7464 & & 1,103 & \\
\hline & 300 & & 1,6962 & & 1,262 & \\
\hline & 300 & & 1,7400 & & 11,114 & \\
\hline & 299 & & 1,7417 & & 11,185 & \\
\hline
\end{tabular}

Tabel di atas merupakan nilai rata-rata dari bandgap. Nilai rata-rata bandgap diperoleh dari merataratakan nilai panjang gelombang dengan nilai absorbansi yang diperoleh dari puncak tertinggi yang dihasilkan oleh alat spektrometer uv-vis. Besarnya nilai rata-rata bandgap secara berturut-turut adalah 3,5826 eV, 2,6888 eV, 2,4222 $\mathrm{eV}$, dan 1,11378 eV. Instrument untuk sampel karbon nanodots (c-dots) kulit bawang menggunakan spektrometer uv-vis dilakukan dengan 5 kali pengulangan. Waktu pemanasan sampel dimicrowave selama 5 menit menghasilkan panjang gelombang rata-rata sebesar 296,6 $\mathrm{nm}$ dan nilai absorbansi rata-rata yang diperoleh sebesar 0,76806. Waktu pemanasan sampel selama 10 menit menghasilkan panjang gelombang rata-rata sebesar 298,2 $\mathrm{nm}$ dan nilai absorbansi rata-rata sebesar 1,21406. Waktu pemanasan sampel selama 15 menit menghasilkan nilai rata-rata panjang gelombang sebesar 298,4 nm dan nilai absorbansi rata-rata yang didapatkan sebesar 1,3186 Sedangkan, waktu pemanasan sampel selama 20 menit menghasilkan nilai rata-rata panjang gelombang sebesar 299,5 nm dan nilai absorbansi rata-ratanya sebesar 1,7408.

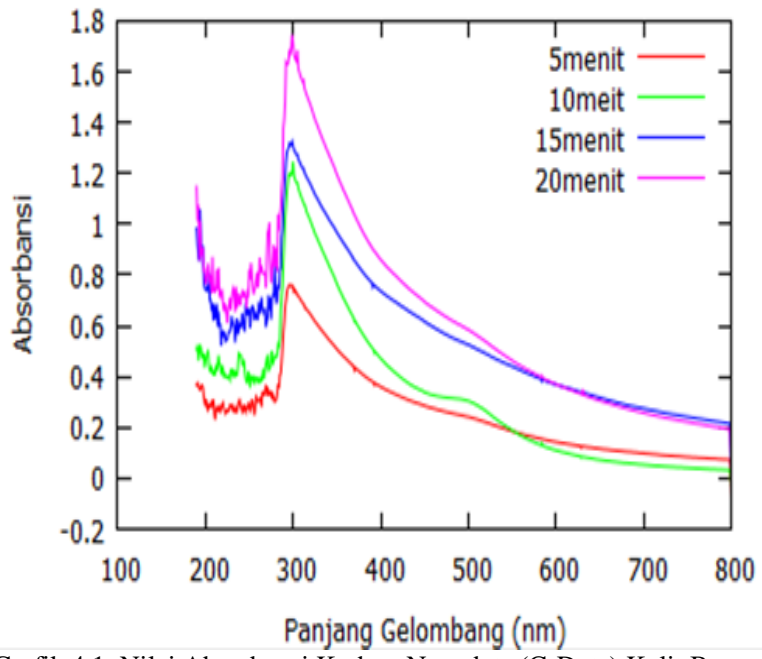

Grafik 4.1. Nilai Absorbansi Karbon Nanodots (C-Dots) Kulit Bawang Merah yang Dikeluarkan Alat Spektrometer Uv-Vis

Grafik diatas menunjukan bahwa sintesis karbon nanodots (c-dots) kulit bawang merah memiliki spektrum absorbansi pada daerah uv.Lamanya waktu pemanasan dalam microwave berpengaruh terhadap nilai absorbansi karbon nanodots (c-dots) kulit bawang merah. Hal ini menunjukan semakin lama waktu pemanasan dalam microwave semakin besar nilai absorbansi yang didapatkan. Selain itu, semakin besar nilai absorbansinya maka semakin kecil bandgap yang dihasilkannya.

Sintesis karbon nanodots (c-dots) berhasil dibuat dalam bentuk larutan yang dapat menyerap spektrum uv pada masing-masing puncak panjang gelombang 296,6 nm (5 menit), 298,2 nm (10 menit), 298,4 nm (15 menit), dan 299,5 nm (20 menit). Gambar 4.1 memperlihatkann penyerapan sinar uv oleh karbon nanodots (c-dots) semakin luas dengan meningkatnya waktu sintesis dan hal tersebut menunjukan karbon nanodots (c-dots) mampu menyerap energi dari sinar uv. Spektrum absorbansi pada daerah uv berhubungan dengan adanya senyawa terkonjungsi pada struktur karbon nanodots (c-dots) dan absorbansi pada daerah tersebut menunjukan adanya mekanisme transisi elektronik didalam orbital $\pi$ aromatik.

Keempat puncak panjang gelombang tersebut memperlihatkan bahwa tepi pita serapan bergeser ke wilayah panjang gelombang yang lebih panjang, sehingga bandgap $\left(\mathrm{E}_{\mathrm{g}}\right)$ yang dimiliki semakin kecil. Bandgap $\left(\mathrm{E}_{\mathrm{g}}\right)$ ini didapatkan dengan metode Tauc Plot berdasarkan spektrum absorbansi dari spektrometer uv-vis dengan rumus $\alpha^{2}=\frac{h c}{\lambda}-E_{g}$. Rendahnya bandgap ini menunjukan energi yang diperlukan untuk eksitasi elektron dari pita valensi ke pita konduksi semakin rendah pula. Hal ini terjadi karena karbon nanodots (c-dots) yang dihasilkan dari proses pemanasan ukurannya semakin besar. Semakin kecil bandgap partikel karbon nanodots (c-dots), maka dimensi ukuran partikel akan semakin besar. Efek pergeseran bandgap akibat perubahan ukuran yang dikenal sebagai quantum effect. 


\section{Simpulan}

Berdasarkan hasil penelitian yang telah dilakukan dapat diambil kesimpulan yaitu sintesis karbon nanodots (c-dots) kulit bawang merah dengan menggunakan teknik microwave berhasil dibuat dalam bentuk cairan. Pemanasan menggunakan teknik microwave dengan variasi waktu berbeda-beda yaitu 5 menit, 10 menit, 15 menit, dan 20 menit. Hasil sintesis karbon nanodots (c-dots) dengan variasi waktu yang berbeda menghasilkan warna dari kuning kecoklatan menjadi kecoklatan.

Lamanya waktu pemanasan selama sintesis karbon nanodots (c-dots) kulit bawang merah mengakibatkan penyerapan spektrum absorbansi yang dihasilkan semakin besar yaitu pada waktu 5 menit, 10 menit, 15 menit, dan 20 menit secara berturut-turut yaitu 0,76806, 1,21406, 1,3186, dan 1,74068. Apabila absorbansi yang dihasilkan semakin besar, maka bandgap yang dihasilkannya semakin kecil dimana nilai absorbansi secara berturut-turut tersebut menghasilkan bandgap sebagai berikut 3,5826, 2,6888, 2,4222, dan 1,11378. Rendahnya bandgap ini menunjukan energi yang diperlukan untuk mengeksitasi elektron dari pita valensi ke pita konduksi semakin rendah juga.

\section{Kepustakaan}

[1] Teru, Valerianus, dkk. 2017. "Pemanfaatan Tepung Kulit Bawang Merah (Allium ascalonicum) Sebagai Imbuhan Pakan Terhadap Penampilan, Profil Darah Dan Kolesterol Pada Puyuh Petelur". Jurnal-jurnal Ilmu Perternakan. Vol. 27 No. 3, Oktober 2017, hlm. 77.

[2] Dior Al Ggifari, Alvin, dkk. 2017. "Analisis Fotoluminesensi Karbon Dot Dari Daun Teh Dan Daun Pepaya dengan Teknik Microwave”. Vol. 6, Oktober 2017, hlm. 20.
[3] Salim A, Agus dan Sudaryanto. 2016. "Penambahan N Pada $\mathrm{TiO}_{2}$ dan Pengaruhnya Pada Energi Band Gap $\mathrm{TiO}_{2}$ Sebagai Bahan Pengolah Limbah”. BATAN. Agustus 2016, hlm. 59.

[4] Murdaka, Bambang dan Tri Kuntoro. 2010. "Fisika Dasar ListrikMagnet, optika, Fisika Modern untuk mahasiswa ilmu-ilmu Eksakta \& Teknik". Yogyakarta: ANDI, hlm. 285.

[5] Qurrata, A, dkk. 2018. "Perbandingan Sifat Optik Karbon Dots (CDots) Dari Daun Mangga Kering Dan Segar”. Seminar Nasional Quantum. Vol. 25, hlm. 626.

[6] Nur Annisa, Siti, dkk. 2016. "Material Karbon Nanodots-Sintesis dan Sifat Luminesensi”, hlm. 1.

[7 ]Ryan Candra Dewi, Adelina, dkk. 2016. “Absorbance Spectrum Carbon Nanodots (C-Dots) Daun Tembakau”.Seminar Nasional Fisika. Vol.5, Oktober 2016, hlm. 129.

[8] Dewi, Rosanti. 2013. “Morfologi Tumbuhan”. Jakarta: Erlangga, hlm. 123.[9]Dewi, Rosanti. 2013. Ibid, hlm. 124

[10] Teru, Valerianus, Op.cit, hlm. 77.

[11]Budianti Soemarie, Yulistia. 2016. "Uji Aktivitas Antiinflamasi Kuersetin Kulit Bawang Merah (Allium Cepta L.) Pada Mencit Putih Jantan (Mus musculus)". Jurnal Ilmiah Ibnu Sina. Vol.1, No 2, Oktober 2016, hlm. 164.

[12] Rahayu, Siti, dkk. 2015. "Ekstrasi dan Identifikasi Senyawa Flavonoid Dari Limbah Kulit Bawang Merah Sebagai Antioksidan Alami”. A1Kimiya. Vol. 2, No. 1, Juni 2015, hlm. 1.

[13] Dany Rahmayanti, Handika, dkk. 2015. "Sintesis Carbon Nanodots Sulfur (C-Dots Sulfur) dengan Metode Microwave”. Unnes Phsycs Journal. Vol 4, No. 1, Agustus 2015, hlm. 2.

[14] Setiawan, Anton, dkk. "Pengembangan Teknologi Microwave Assited Extraction (Mae) Sebagai Alternatif Peningkatan Kadar Zingiberen Ginger Oil Dari Limbah Ampas Jahe Industri Jamu”. Jurnal Ilmiah Cendekia Eksakta, hlm. 2.

[15] Giancoli, Dauglas C. 1999. “Fisika Edisi Kelima Jilid 2". Jakarta: Erlangga, hlm. 305

[16] Novianto, Fajrin, dkk. 2014. "Keteprofen, Penetapan Kadarnya dalam Sediaan Gel dengan Metode Spektrofotometer Ultraviolet-Visibel". Jurnal Pharmacy. Vol. 11, No. 01, Juli 2014, hlm. 2.

[17] Alberty, Robert A, dkk. 1981. "Edisi Kelima Kimia Fisika Jilid 2". Jakarta: $\quad$ Erlangga, hlm. 